\title{
Ode til kasuistikken
}

Jeg reiser motstrøms med Kolsåsbanen. Året er 1953. Det er både plass, tid og ro til fordypning i faget. Mellom Egne hjem og Bekkestua hopper jeg i setet. Hun må ha lest journalen vår, tenker jeg: Sykehistorien i Pediatrics er en blåkopi av vår pasients. «Hyperkalsemi hos en gutt immobilisert for lårbeinsbrudd $\mathrm{nr} .2 \mathrm{i}$ verdenslitteraturen,» står det. $V i$ hadde ikke stilt diagnosen Katharine Dodd gjorde det for oss (1). Det var enkelt å bekrefte den, og det var ikke mye mobilisering som skulle til.

Det var bare en kasuistikk, ja vel, men et bidrag til forståelse av sammenhengen. Flere biter falt på plass. Det var god informasjon og jeg fikk min første treningsøkt i formidling (2).

Koma og ekstrem blekhet forekommer sjelden ved invaginasjon og mekanismen er ukjent. På et ukentlig rutinebesøk på biblioteket for å bla i nye tidsskrifter sprang en tittel i øynene: «Early coma and intussesception: Endogenous opioid induced» (3). En uttalt miose hos et spedbarn i koma ledet tankene hen på opiumsforgiftning.
Forfatterne ga nalokson, med dramatisk effekt. Hun våknet umiddelbart, pupillene utvidet seg, men hun gikk i koma igjen etter en halv time. To nye doser med nalokson ga samme resultat. Etter 24 timer ble invaginasjonsdiagnosen stilt.

Pytt, det var bare et enkelttilfelle. Det beviser ingenting. Nei, det gjør ikke det, men det peker på en forklaring som kan etterprøves og undersøkes nærmere. En endorfineffekt utløst av smerter virker plausibelt. Miose var ikke beskrevet tidligere. Vi fant det ikke i våre journaler heller men var det undersøkt, målrettet? Nå vil det alltid bli spurt om - i en overskuelig periode iallfall.

Det er andre tider nå enn det som beskrives over. Feil! Det er nesten like mye ubeskrevet nå som for 20 eller 50 år siden. Vi bare skraper på overflaten. Tenk på alle de nye medikamentene, på alle dem vi fyller oss selv og pasientene med. Hver pasient er nesten et nytt eksperiment. Det tar tid å avsløre sjeldne bivirkninger og interaksjoner. Bare søk på «Proton pump inhibitors and myopathy». Du vil bli overrasket.

Leve den miskjente kasuistikken. Den har fortsatt noe å bidra med. Den er fortsatt noe å lære av. Og den er god trening i startfasen.

\section{Sverre Halvorsen}

Midtstugrenda 120

0787 Oslo

Oppgitte interessekonflikter: Ingen

\section{Litteratur}

1. Dodd K, Graubarth H, Rapoport S. Hypercalcemia, nephropathy and encephalopathy following immobilization; case report. Pediatrics 1950; 6: 124-30.

2. Halvorsen S. Osteoporosis, hypercalcemia and nephropathy following immobilization of children. Acta Med Scand 1954; 149: 401-8.

3. Tenenbein M, Wiseman NE. Early coma in intussesception: Endogenous opioid induced? Pediat Emerg Care 1987; 3: 22-3.

Manuskriptet ble mottatt 17.2. 2010 og godkjent 19.3. 2010. Medisinsk redaktør Anne Kveim Lie.

\section{Kan vi tenke nytt sammen?}

800000 nordmenn befinner seg utenfor ordinært arbeidsliv, nærmere 350000 personer mottar uføreytelser og Norge er et av de land i Europa med høyest andel av befolkningen i arbeidsfør alder på permanente trygdeordninger. Dagens tilbud er gått ut på dato. La oss gjøre noe sammen!

Jeg er ikke lege og kan dermed ikke uttale meg om utbrenthet innenfor det medisinske felt, men jeg kan uttale meg på bakgrunn av egen erfaring. Menneskets psykologi har alltid opptatt meg. Da jeg var i begynnelsen av 20-årene, tok jeg mine første kurs i personlighetsutvikling i England, og siden den gang har både kurs og skoler vært mange. Jeg er utdannet innenfor ledelse ved BI og er psykoterapeut gjennom en fireårig utdanning fra Danmark og har mange års salgsledelse i ryggen.

Det er rundt sju år siden jeg selv ble utbrent, og i tiden som fulgte møtte jeg mange i samme situasjon. Jeg opplevde at mange slet mer enn meg og forsto at kombinasjonen av en medfødt indre kriger og forståelsesfulle saksbehandlere hos NAV, en god psykolog og en flott lege gjorde at jeg kom i mål. Jeg møtte tusenvis av «utbrente» sjeler der ute som gjerne ikke hadde diagnosen utbrent, men som $i$ alle fall oppførte seg på en måte som minnet sterkt om mine egne symptomer, og som ikke ble sett!

Min erfaring tilsier at det er et skrikende behov for tiltak rettet mot det friske i mennesket og hvor man tenker helhetlig. Jeg har nå lyst til å starte et prosjekt i Tyrkia og har konkrete planer. Er det noen leger der ute som kunne tenke seg å være med på dette, ville jeg sette pris på om de tok kontakt!

\author{
Irene Kingswick \\ irene_kingswick@hotmail.com \\ Fæsteråsen 90 \\ 5184 Olsvik \\ Oppgitte interessekonflikter: Ingen \\ Manuskriptet ble mottatt 7.10. 2009 og godkjent \\ 27.11. 2009. Medisinsk redaktør Anne Kveim Lie.
}

